\title{
Socio Economic Conditions of the Hatchery Labors in Chanchra Area of Jessor District in Bangladesh
}

\author{
Tahmina Siddika, Ripon Kumar Adhikary, Md. Hasan-Uj-Jaman", Shoumo Khondoker, \\ Nazia Tabassum, Md. Farid Uz Zaman
}

Department of Fisheries \& Marine Bioscience, Jessore University of Science \& Technology, Jessore, Bangladesh

Email address:

tahmina.siddika.sathi@gmail.com (T. Siddika),ripon03@yahoo.com (R. K. Adhikary), hasan100401@gmail.com (M. Hasan-Uj-Jaman), shoumo100429@gmail.com (S. Khondoker),naziakeka@gmail.com (N. Tabassum), farid100422@gmail.com (M. F. U. Zaman)

${ }^{*}$ Corresponding author

\section{To cite this article:}

Tahmina Siddika, Ripon Kumar Adhikary, Md. Hasan-Uj-Jaman, Shoumo Khondoker, Nazia Tabassum, Md. Farid Uz Zaman. Socio Economic Conditions of the Hatchery Labors in Chanchra Area of Jessor District in Bangladesh. Agriculture, Forestry and Fisheries. Vol. 5, No. 3, 2016, pp. 30-36. doi: 10.11648/j.aff.20160503.11

Received: April 28, 2016; Accepted: May 6, 2016; Published: May 23, 2016

\begin{abstract}
The study was conducted on the hatchery labors in some selected area of Jessore Sadar Upazila in Bangladesh under the district of Jessore by using a logical questionnaire on socio-economic condition of hatchery labor. The main objective of the study is to know the socio-economic condition of the hatchery labors in some selected area of Chanchra region of Jessore district. The specific objectives are to know the different labor categories in hatcheries of Chanchra region and to know the socio-economic condition of hatchery labors. A total of 40 hatchery labors were selected and interviewed. It was found that the average age group of hatchery labor is 26-35 years, predominantly all of them are male and any presence of female labor was not found. It was found that about $95 \%$ labor use tube-well water and $5 \%$ use deep tube-well water. Regarding mean of transport, $65 \%$ labor move by on foot. It was found that about $75 \%$ hatchery had no medical treatment facility. However, further study about the socio-economic condition is needed and institutional, organizational, technical and credit supports are needed for their better socio-economic and sustainable livelihood.
\end{abstract}

Keywords: Fish Hatchery, Hatchery Labour, Socio-economic Status, Sustainable Livelihood and Bangladesh

\section{Introduction}

Fisheries sector is playing a vital role regarding employment generation, animal protein supply, foreign currency earning and poverty alleviation Hossain et al., [1]. Bangladesh is blessed with huge water bodies in the form of pond, natural depressions (haors and beel, lakes, canals, rivers and estuaries covering an area of 45,75,706 hectares (ha.) DoF [2]. The inland water bodies are rich in freshwater fish species comprising 260 indigenous, 12 exotic and 24 fresh water prawn species DoF [2]. Fisheries sector contributes $4.39 \%$ to the national GDP and almost one-fourth $(22.76 \%)$ to the agricultural GDP Bangladesh Economic Update [3]. In recent years, this sector performs the highest GDP growth rate in comparison to other agricultural sectors (crop, livestock and forestry).The growth rate of this sector over the last 10 years is almost steady and encouraging; varying from 4.76 to 7.32 percent with an average of 5.61 percent DoF [4]. The sector's contribution to the national economy is higher than its' $4.39 \%$ share in GDP, as it provides about $60 \%$ of the animal protein intake and more than $11 \%$ of the total population of the country is directly or indirectly involved in this sector for their livelihood DoF [4].

Fisher folk are considered as one of the most backward sections in our society. Information on socio-economic framework of the hatchery labors forms a good base for planning and development of the economically backward sector. Lack of adequate and authentic information on socioeconomic condition of the target population is one of the serious impediments in the successful implementation of development programme. A socio-economic condition is sustainable when it can cope with and recover from stress and shocks and maintain to enhance its capabilities and assets both now and in the future. 
Fish hatcheries and nurseries were not grown in symmetry in all region of Bangladesh. Jessore district is the center point for fry and hatchling production as it is a potential and profitable business avenue in this region. At Jessore the numbers of total hatchery are 35 and 361 nurseries. The total production from these hatcheries and nurseries were respectively $52,639 \mathrm{~kg}$ hatchlings and $60,10,600 \mathrm{~kg}$ fry in 2013 (Upazila Fisheries Office, at Jessore Sadar 2013). In this aspect, hatchery labor plays a vital role and they are one of the most valuable communities in Bangladesh. They are poor by any standard. They lead a miserable life. The living condition the standard of living of hatchery labors would mainly depend upon the income earned by them. It will also depend upon the number of employment days available in a month.

The study is needed to portray the socio-economic condition of hatchery labors in Chanchra region of Jessore districts with a view to obtain some knowledge about their social and economic condition and to provide some guidelines which would be economically acceptable. The main objective of the study is to know the socio-economic condition of the hatchery labors in some selected area of Chanchra region of Jessore district. The specific objectives are to know the different labor categories in hatcheries of Chanchra region and to know the socio-economic condition of hatchery labors.

\section{Materials and Methods}

\subsection{Study Area}

The study area was Chanchra dalmill, Sabjibag complex and Kotbel Tola in Chanchra region of Jessore district in Bangladesh. Ma Fatema hatchery, Hamja hatchery, Suvro hatchery situated in Chanchra Dalmill, Rupali, Sonali, Anan hatchery situated in Sabjibag complex, Kapotakho, Chaudhuri Mausso, Mudumoti hatchery situated in Kotbeltola. The location of Chanchra region is presented in figure.

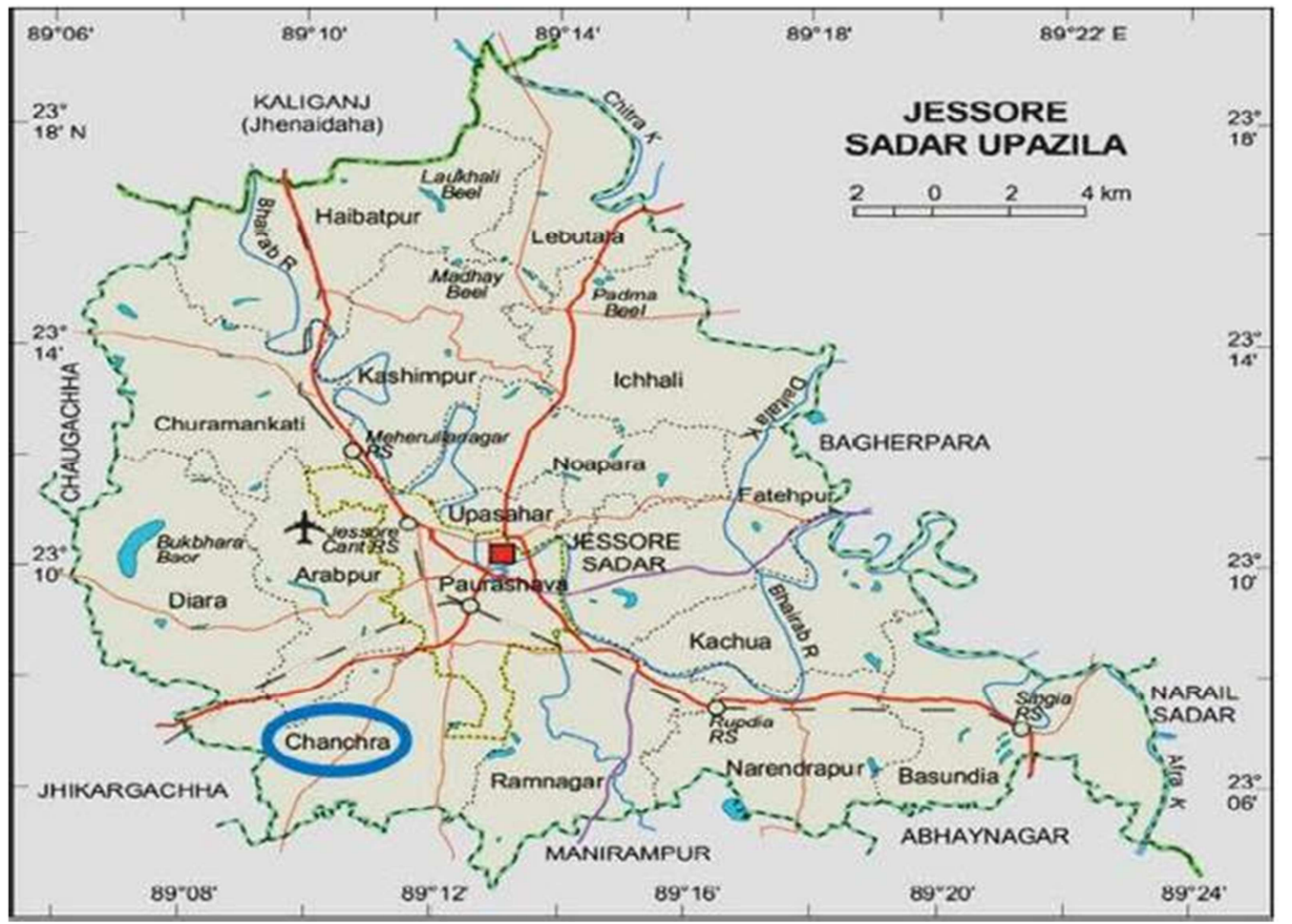

Figure 1. The location of Chanchra region.

\subsection{Field Survey and Observation}

For collecting data on socio-economic condition of hatchery labors, survey was conducted in three places in Chanchra region. 40 labors were randomly selected. Personal interview were conducted with various aspects of effectiveness.

\subsection{Questionnaire Survey}

To collect data on socio-economic condition of the selected area, the most important matter is to prepare the questionnaire. The questionnaire was developed in logical sequences, so that the labors can answer chronologically.

\subsection{Data Collection}

\subsubsection{Primary Data}

Primary data were collected from the fishermen by researcher himself. Several visits were made to the study area to collect appropriate information related to objectives of the study.

\subsubsection{Secondary Data}

Secondary data were collected from a previous research, Newspaper, Upazila Fisheries Offices and DoF and DFID [5] to clarity. 


\subsection{Data Analysis}

The study used both primary and secondary data in conducting the analysis. Collected information obtained from the survey were accumulated, grouped and interpreted according to the objectives as well as parameters of interested. Some data contained numeric and some contained narrative facts. The data were then presented in graphs and tabular forms. For processing and analysis purpose, MS Excel and MS Word have been used.

\section{Results}

A total of 40 labors were interviewed from the study areas. Various indicators were collected in different aspects of livelihood characteristics of the labors. A detailed analysis were made on the following way and presented in the section.

\subsection{Age Group and Gender Type}

From the survey, it was found that 4 labors (10\%) belong to under 18 age, 10 labors (25\%) belong to between 18-25, 18 labors (45\%) belong to group between 26-35, 6 labors (15\%) belong to group 36-45 and reaming 2 labors $(5 \%)$ were belong to above 45 age. Fig. 2 shows that highest number of the labors was between 26-35 age groups.

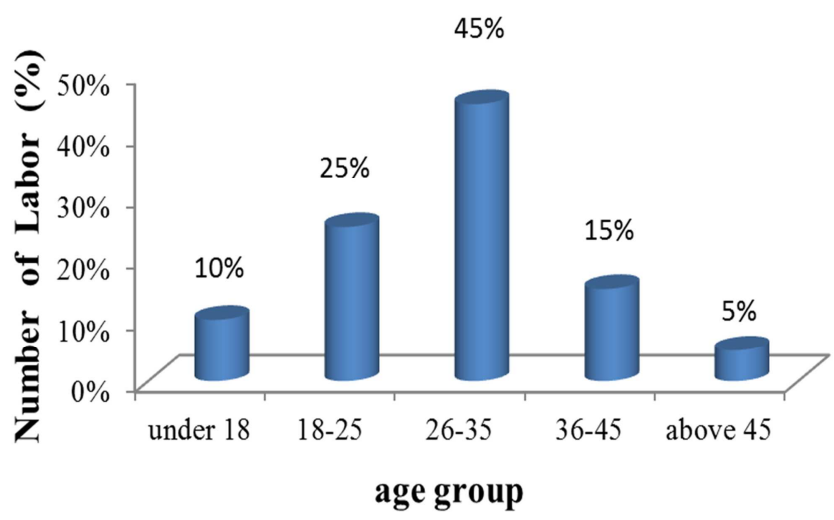

Figure 2. Age group of the labor.

In addition, all labors were male and there is no female contribution. For hatchery working, male gender is very suitable because hatchery operation is very hard. For this reason, there had $100 \%$ male contribution and $0 \%$ female contribution.

\subsection{Type of Labor and Working Hour}

From the interview, it was found that many labors work as permanent worker and some labors work as casual labors in peak season. Sometime day basis, contractual labors can be found and this variation created on the basis of working condition. About $90 \%$ labor work as permanent and $10 \%$ labors work as (contractual, casual, day basis). Labor type of study area in Fig. 2.

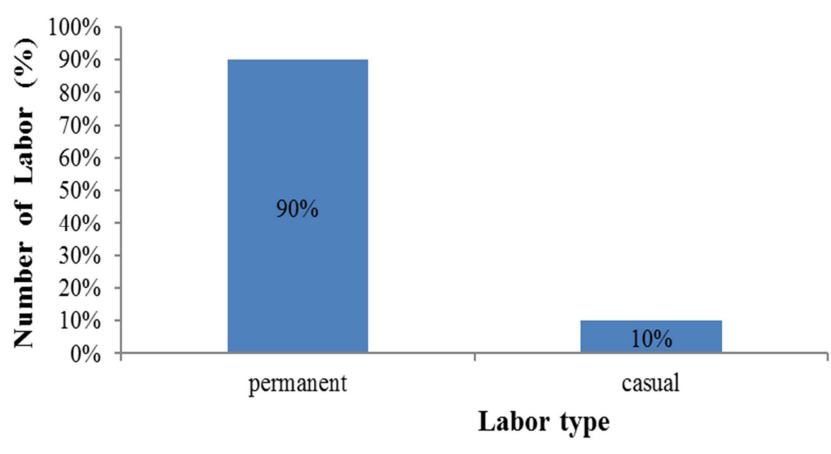

Figure 3. Type of Labor.

It was also found that all permanent labor work in 24 hour but basically they work strength in 8 hour, sometime this working duration should be 12 hours. Few labors work about 2-4 hours for their side income.

\subsection{Income Range and Communication Status}

Mainly income range of the hatchery labor is based on monthly basis. The highest number of labor were found which had income range in between 5000-8000, about 53\% labors and about $29 \%$ labor involved in between $8500-12500$ and few labor like (18\%) belong to group between 12500 16000. Income range of study area is shown in fig. 4.

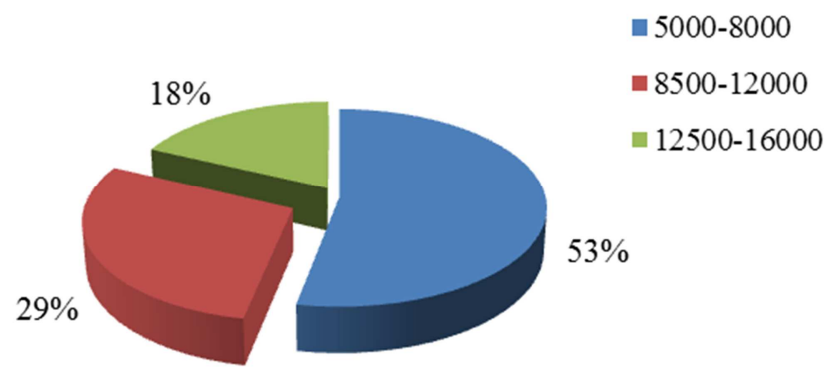

Figure 4. Income range (based on monthly basis).

On the other hand, it was revealed that all labor had mobile phone facility for their communication feature. Because nowa-days mobile phone medium is so much easy and cheap way for communication facilities for all class of labors.

\subsection{Unemployment Situation and Side Work}

As the survey focused that, hatchery labor had no unemployment period, every time they involved in any type of work which include in hatchery activity. But in the peak season, they did so hard work than the other period. From the survey; it revealed that hatchery is a very busy working sector. Side work means involvement in another work except their main work, but hatchery labor had no easy opportunity to involve in another work except hatchery activity. Their side work mainly included in hatchery related. From the side work, they earned 200-3500 BDT in a month. Some labor made poly bag. Some work as delivery helper, some labor earned from boksis. Few well labors have own fish business out of hatchery (Table 1). 
Table 1. List of side work.

\begin{tabular}{ll}
\hline Side work & Amount of BDT \\
\hline Making poly bag & $750-900$ \\
Earning from boksis & $250-400$ \\
Delivery helper & $700-3000$ \\
Selfish farming business & Above 2000 \\
\hline
\end{tabular}

\subsection{Educational Status and Religious Status}

From the survey, we found that most of the labor was literate. About 57\% labor had passed primary level, about $13 \%$ had secondary level, there had no any S.S.C, HSC educational level labor in hatchery, and about $30 \%$ were illiterate. Fig. 5 showed educational status. Religion can play a very important role in the socio-cultural environmental life of labors. In the study area, 95\% labors were Muslims and $5 \%$ labors were Hindus. Religious status from the questionnaire interview is shown in the Fig. 6.

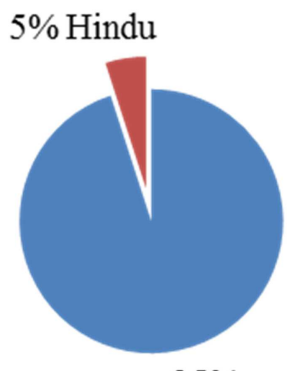

$95 \%$

Muslim

Figure 5. Educational Status of hatchery labour.

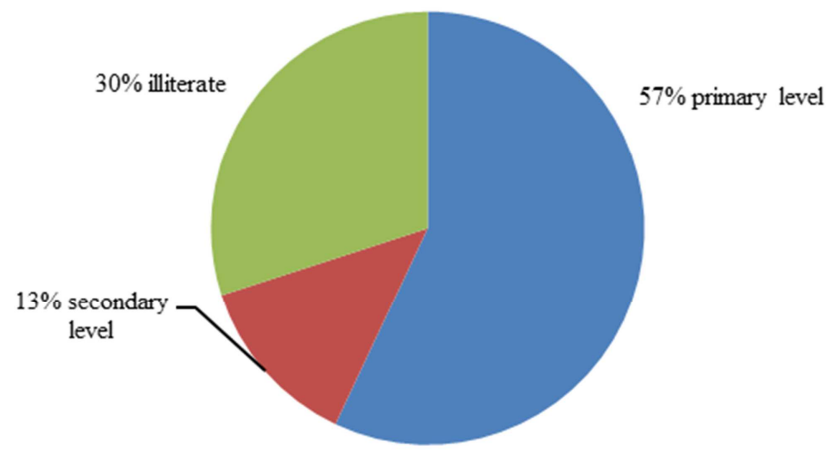

Figure 6. Religious Status of Hatchery Labors.

\subsection{Family Type, Size, House Ownership and Land Ownership}

In the study area, it was found that average labors live in joint family (group of labors related by blood or by law) and some labor live in Nuclear family (married couples with children). About (22\%) labor live in nuclear family. The highest percentages obtained in the 4-5 members and this amount was $50 \%$. About (28\%) included in 6-8 members (Fig. 7) showed family size.

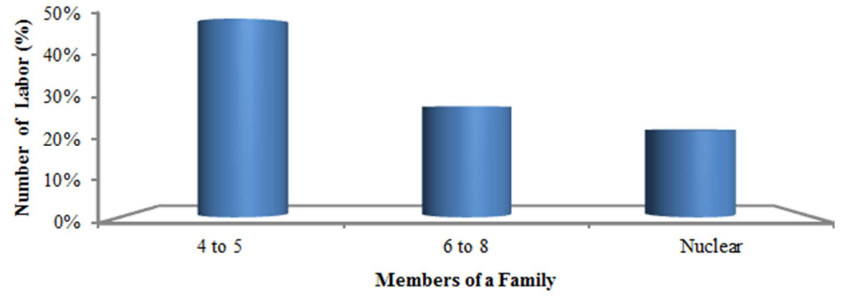

Figure 7. Family Size of hatchery labors.

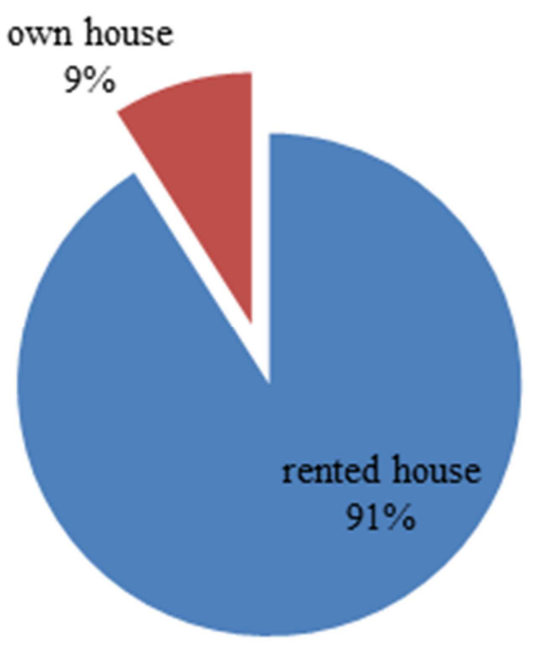

Figure 8. Ownership of the house.

In this area most of the families were living in rented or shared house. The survey result also revealed that about (91\%) labor live in rented or sheared house and about (9\%) labor live in own house (Fig. 8) shows ownership of the house. Highest percent labor had no land ownership, only few labors had little land ownership. About 95\% labor had no land ownership and about 5\% labor had little land ownership.

\subsection{Drinking Water Availability, Electricity Facilities and Supporting Agencies for Hatchery Labor}

In the survey, it was found that all labor had pure drinking water facility in their hatchery and their living house. So they were free from water causing diseases.

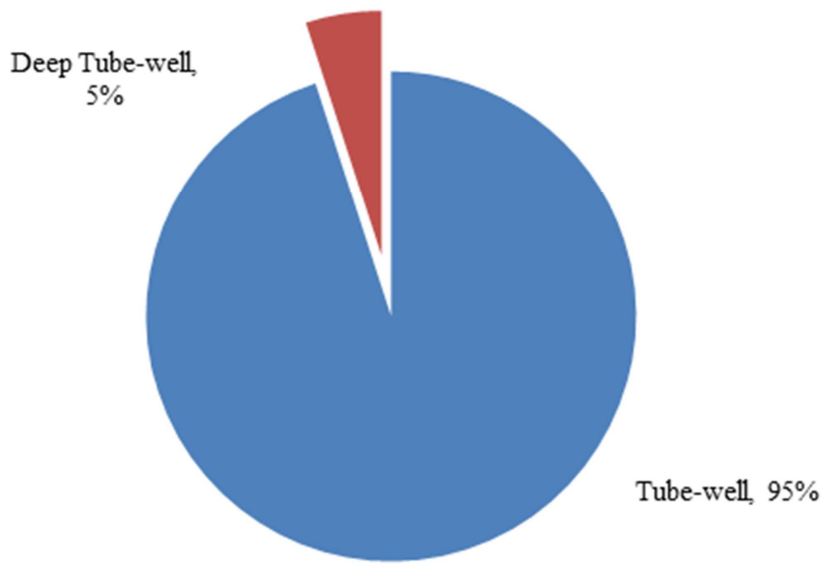

Figure 9. Drinking water facilities of hatchery labor. 


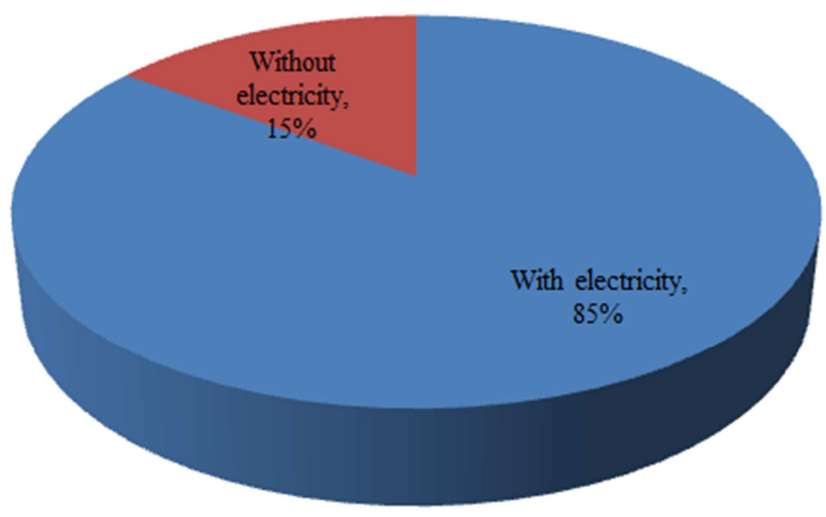

Figure 10. Electricity facilities of hatchery labor.

Maximum labor use tube-well water, some labor use deep tube-well water. About $95 \%$ use tube-well water and 5\% use deep tube-well water (Fig. 9). In addition, it was found that majority households $(85 \%)$ had electricity facility, only a few labor $(15 \%)$ were found to no facilities electricity (Fig. 10). In this area labor were helped by different organization like BFRI, World Fishing Center, Mutsho Odhidoptor gave technical support, training facilities. BFRI gave support 2 times in a year.

\subsection{Mean of Transport and Media of Entertainment}

In the study area, maximum labor live in hatchery nearest place, for this reason average labor come in the hatchery by on foot, or bicycle. Some labor comes by rickshaw or van, this labor live in far distance from the hatchery. About $65 \%$ labor come by on foot, about $25 \%$ labor used bicycle for moving and about $10 \%$ labor used other way like rickshaw or van.

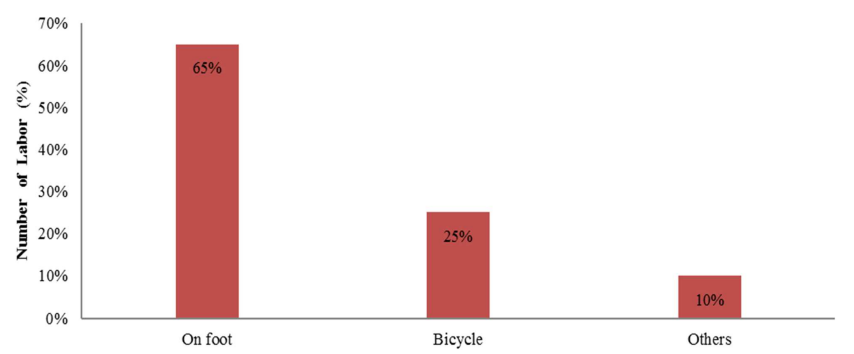

Figure 11. Mean of transport of hatchery labor.

Entertainment must be need for removing boring condition or acquire some new energy for all class of labors. For this reason, hatchery labor enjoys their entertainment and maximum labor use television for their entertainment. Because nowadays the television has become more popular entertainment media than other media.

\subsection{Nutrition Status, Medical Treatment Facilities and Health Condition}

From the survey, It was attempted to collect information on extent of food and nutrition intake which for socioeconomic assessment of the labors, health in particular. The survey revealed that maximum labor took nutrias food.

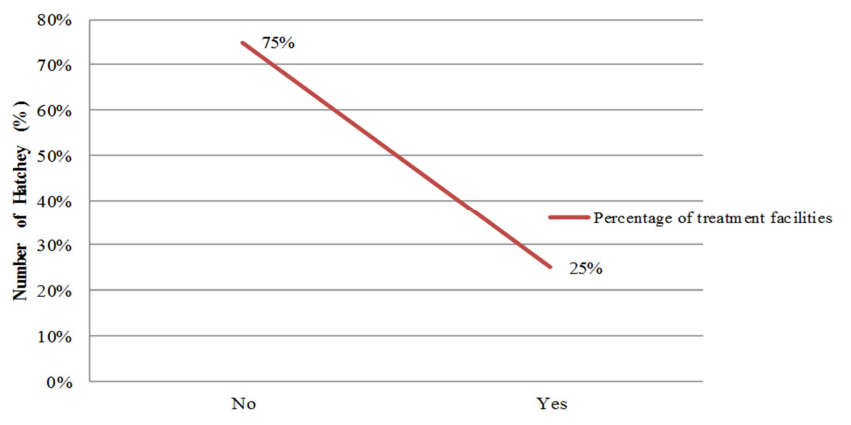

Figure 12. The medical treatment facilities in the hatchery labour.

All labor intake fish meal, vegetable and fish obviously nutrias food. The hatchery labors were suffered from different diseases, like fever, dysentery, gastric, diarrhea etc. To prevent this diseases condition, they require medical treatment facilities. The study shows that maximum hatchery had no medical treatment facilities; about (75\%) hatchery had no medical treatment facilities. For this reason, they took quack treatment against diseases and about (25\%) hatchery had this facilities Fig. 12. It was found that maximum labor were medium healthy, a few labor become un-healthy. For the hard working, labor must need healthy body, for this reason maximum labor had medium healthy body.

\section{Discussion}

The total study shows that the highest numbers of hatchery labors (45\%) were belonged between 26-35 years age. Kostori [6] reported that majority (36\%) fishermen of the Chalan Beel were belonging to age group of 20 to 30 years. Most of the labors of selected area were Muslims (95\%); beside this only 5\% labors were Hindus. But Raju [7] found $14.33 \%$ Hindus and $85.67 \%$ Muslims in Sailkupa Upazila. From this survey I found that female worker are not very interested with hatchery work rather they involved in household and agriculture work. Verite [8] reported that approximately 46.6 percent of respondents were male and 53.3 percent of respondents were female. From this study, $57 \%$ labor had passed primary level, about $13 \%$ had secondary level, there had no any S.S.C, HSC educational level labor in hatchery, and about $30 \%$ were illiterate but Bappa, et al., [9] reported that the illiteracy level of majority fishermen $(60 \%)$ in the study area was found illiterate and only a small portion (10\%) passed SSC/HSC examinations. In the study area, it was found that $22 \%$ labor live in Nuclear family, $88 \%$ live in joint family. The highest percentage of family size was obtained 4-5 members' family (50\%). Mahbubullah [10] states $44 \%$ of the family's size to be at 6 to 8 in members. The present survey shows that majority percentage of the labors had electricity connection (85\%) and minority percentage of the labors had no electricity connection (15\%). Kostori [6] reported 48\% labors had no electricity facility in a community of chanlan Beel under Tarash Thana in Sirajganj district. In the study area there were $57 \%$ primary level educated, $30 \%$ were illiterate. DoF [4] in Chanda beel and Ahmed [11] in Tangail found literacy 
rates were $45 \%$ and $69 \%$, respectively. The $95 \%$ were found to use tube-wells, others (5\%) using deep tube-wells. From the study it can be said that hatchery labor are conscious about their health because safe drinking water is a very important factor for good health. Ali, et al., [12] where $88 \%$ fish farmers used their own tube-well in Rajshahi district. But Ahmed [11] mentioned that most farmers used pond water due to lack of tube-well in coastal area. In the survey area it was found that average number of labor like (53\%) mean monthly income was 5000-8000. Pravakar, et al., [13] reported that annual income of fish farmers varied from $24,000-1,00,000$ BDT. From the study shows that only $5 \%$ of the labors had land ownership and the majority $95 \%$ of the labors were landless. Islam, et al., [14] found that $2 \%$ fishermen were landless. From the survey, it was found that all permanent labor work in 24 hour but basically they work strength in 8 hour. Verite [8] reported that nearly half (47.1 percent) of all respondents reported having worked 11-15 hours, with an absolute average among all workers interviewed of 10.5 hours. The total study shows that $90 \%$ labor worked as permanent worker and $10 \%$ labor worked as casual worker (on the basis of type of work). Verite [8] reported that 92 percent of contract workers interviewed reported working 7 days per week compared to 76 percent of permanent workers interviewed.

\section{Problems and Recommendations}

The following problems have identified by asking and relevant questions to the labors of the area:

- This is so many hard working.

- Maximum don't get sufficient amount of BDT.

- Insufficient medical treatment facilities in the hatchery.

- Lack of female worker opportunity.

- Lack of proper sleeping condition.

The recommendation for these problems are-

- Need to appropriate relax time for removing their tiredness mode.

- Give sufficient amount of BDT to fulfill their needs.

- Better job opportunity should be created for female in the hatchery.

- To ensure proper sleeping situation for better work and good health.

\section{Conclusion}

Chanchra area of Jessore district is one of the hatchery regions in Bangladesh. Many people survey this hatchery as a hatchery labor. This hatchery labor plays a great role and do hard work for hatchery development. As a socio-economic point of view, hatchery labors lid a simple life due to lack of sufficient amount of money. They do so many hard works and get insufficient facilities from the hatchery. Maximum, they do not get opportunity to do any kind of side work out of hatchery. They require adequate training facilities to improve their working skill, better amount of BDT and increase awareness among labors to improve their socio- economic condition.

\section{Acknowledgement}

The authors would like to thank the chairman of Fisheries and Marine Bioscience Department, Jessore University of Science and Technology, Jessore, Bangladesh and the hatchery owner of these hatcheries in Jessore Bangladesh for permeating the research team to carry out the quality assessment process in the laboratory.

\section{References}

[1] Hossain, M. S., Khan, R. H., Akter, A., (2011). Feasibility of underground water for fish culture in the southern region of Bangladesh: a case study from Laxmipur and Chittagong area. J. Agrofor. Environ. 5 (2): 121-123.

[2] DoF (Department of Fisheries), (2008). Matshaya Sampad Unnayon Ovigun, Ministry of Fisheries and Livestock. Government of the Peoples Republic of Bangladesh. pp. 79- 81.

[3] Bangladesh Economic Update (2012). Poverty Reduction and Economic Management, South Asia Region. Funded by the World Bank.

[4] Department of Fisheries, (DoF) (2013). Fisheries Statistical Yearbook of Bangladesh 2011-2012. Fisheries Resources Survey System (FRSS), Department of Fisheries, Bangladesh. (29): 44.

[5] Department of Fisheries (DoF) and Department for International Development (DFID) (2002). Management options for the shrimp fry fishery, A regional stakeholder workshop in Khulna.

[6] Kostori, M. F. A., (2012). Socio-economic condition of Fishermen of the ChalanBeel under Tarash Thana of Sirajganj in Bangladesh. Bangladesh Research Pulications. Journal 6 (4):393 402.

[7] Raju, A., 2002. Livelihood status of fish farmers in Sailkupa Upazila under Jhenaidah District. M. Sc thesis. Fisheries and Marine Resource $\mathrm{T}$ echnology Discipline, Khulna Uni, Bangladesh. pp. 53.

[8] Verite (2012). Research on Indicators of Forced Labor in the Supply Chain of Shrimp in Bangladesh.

[9] Bappa SB, Hossain MMM, Dey BK, Akter S and Hasan-UjJaman M (2014), Socio-economic status of fishermen of the Marjat Baor at Kaligonj in Jhenidah district, Bangladesh. Journal of Fisheries 2(2): 100-105.

[10] Mahbubullah, M., (1986) Case study of polder and estuarine fisheries community in Bangladesh. In Socio-economic Study of Tropical Fishing Community in Bangladesh. A report for Food and Agricultural Organization (FAO), Rome. pp. 12-14.

[11] Ahmed, N. U., (1999). A study on socio-economic aspect of coastal fishermen in Bangladesh, Department of Fisheries. Bangladesh Agricultural University, Mymensingh, Bangladesh.

[12] Ali, M. H., M. D. Hossain, A. N. G. M. Hasan and M. A. Bashar (2008). Assessment of the livelihood status of the fish farmers in some selected areas of Bagmara Upazilla under Rajshahi district, J. Bangladesh Agri. Uni., 6(2): 367-374. 
[13] Pravakar, P., Sarker, B. S., Rahman, M. and Hossain, M. B. (2013). Present Status of Fish Farming and Livelihood of Fish Farmers in Shahrasti Upazila of Chandpur District, Bangladesh. American-Eurasian J. Agric. \& Environ. Sci. 13 (3): 391-397.
[14] Islam, M. R., Hoque, M. N., Galib, S. M., Rahman, M. A., (2013). Livelihood of the fishermen in Monirampur Upazila of Jessore District Bangladesh. Journal of Fisheries. 1 (1): 37-41. 